\title{
Professor Miloslav Krsiak 1939 - 2016
}

\author{
Magdalena Sustkova-Fiserova $^{1} \cdot \operatorname{Ian}_{\text {Stolerman }}{ }^{2}$
}

Received: 10 October 2016 / Accepted: 12 October 2016 / Published online: 20 October 2016

(C) Springer-Verlag Berlin Heidelberg 2016

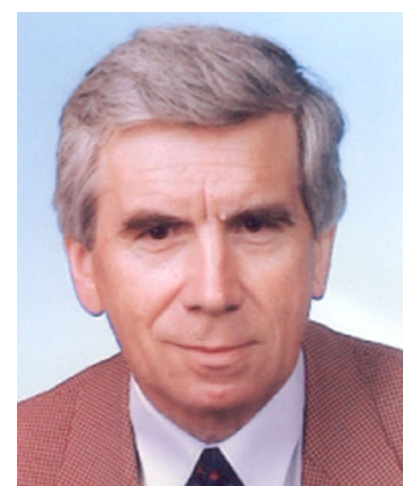

Professor Miloslav Kršiak MD, FCMA was born on 7 May 1939 in Bratislava, Slovakia. He studied in Prague at the Faculty of Paediatrics, Charles University, and was awarded a Graduate Doctor degree in 1962. It was upgraded to a Medical Doctor degree (MD) in 1966; he defended his degree for the Candidate of Medical Sciences at the Department of Pharmacology of The Czech Academy of Science, where he was a research assistant. His professional growth was then supported by a Postdoctoral Fellowship at

Magdalena Sustkova-Fiserova

magdalena.sustkova@1f3.cuni.cz

Ian Stolerman

ian.stolerman@kcl.ac.uk

1 Department of Pharmacology Third Faculty of Medicine, Charles University, Ruska 87, 10000, 10 Prague, Czech Republic

2 Department of Addiction, Institute of Psychiatry, Psychology and Neuroscience, King's College London, De Crespigny Park, London SE5 8AF, UK the Department of Pharmacology, University College London (1967-1969). Milos was honoured by the award of the degree of Doctor of Medical Sciences from Charles University in 1982 and continued as a senior academic until 1991, when he became head of the Department of Pharmacology of the Third Faculty of Medicine of the Charles University in Prague.

Milos's period of postdoctoral study in London was marked not just by scientific achievement but also by considerable anguish associated with the Soviet invasion of Czechoslovakia in 1968. There was an opportunity for him to remain in London but he and his wife Milena (who was also in London) decided that the call of his homeland and family was too powerful and they returned to Prague in 1969. While in London, he collaborated with Hannah Steinberg and Ian Stolerman in work embracing ethological studies of interanimal interactions and notable investigations of methods for studying the locomotor activity of individual rodents. Firm friendships were forged and survived despite only occasional personal meetings when Milos was able to obtain permission to attend meetings outside Czechoslovakia. He took the opportunities that these trips provided to obtain a broader view of world events than was possible in his homeland at that time. During one of these trips to the West, he met Klaus Miczek at the 1974 CINP congress in Paris, and this was the beginning of a life-long collaboration and friendship with several laboratory exchanges.

The main domain of his scientific activities was behavioural pharmacology and especially social behaviour including aggression, in which he was recognised internationally as a leader of the field. Milos's work was published in high impact journals and frequently cited, but he was also devoted to the education of graduate students. His department at Charles University included a superb ensemble of talented graduate students who 
under his guidance achieved significant professional success. He was one of the most cited experts in behavioural pharmacology. In addition to other experimental models, he was especially involved with the development of a specific arrangement of the social conflict test in mice, an experimental model for the study of anxiolytic compounds that has been used extensively. Milos was also devoted to the study of pain. He was a founding member of the Czech peer-reviewed journal "Bolest" (Pain) in 1997 and contributed significantly to monographs that focused on pharmacology of pain, thereby gaining the Charles University Rector's Award (1997) and an Award of Presidium of the Czech Medical Society of Jan Evangelista Purkyně (2013). Milos was also a co-author of some important patents and participated in the development and preparation of medicinal preparations that are still in use. One of the most frequently sold over-the-counter combination analgesics in the Czech and Slovak Republics is "Ataralgin", comprised of acetaminophen, guaifenesin and caffeine.

Milos also took part in the activities of many scientific societies and contributed to the general organisation and systematisation of science in the Czech Republic. He was a founder member and enthusiastic supporter of the European Behavioural Pharmacology Society (EBPS) from 1986 and served on its managing committee. In 2004, he became a founder member of the Czech Medical Academy and since 2010 was a member of its board, serving as Vice-Chairman (2010-2013). He was a long-time member of the Czech Society of Experimental and Clinical Pharmacology and Toxicology board and chairman and board member of the Czech Medical Society of Jan Evangelist Purkyně, and subsequently, he was an honorary member of this society. Likewise, Milos was a member of the Czech Neuropsychopharmacological Society and its Board and was also an honorary member of this society. He worked as a member of other organisations such as the Society for
Investigation and Treatment of Pain, Society of Psychosomatic Integrations, Society of Czech Physicians in Prague and the Czech and Slovak Ethological Society.

During his distinguished career, Milos won many prestigious awards, including the Purkyně Medal of the Czech Medical Society, the Medal of Faculty of Pediatrics, the Third Faculty of Medicine Charles University in Prague Medal and the Medal of Charles University. He was also a member of the Praesidium of the Scientific Board of the Ministry of Health of the Czech Republic, the Advisory Board of The Czech Republic State Institute for Drug Control. Milos was also a member of grant-awarding committees such as the Czech Science Foundation, Grant Agency of Charles University and the Grant Agency of the Czech Academy of Science; nevertheless, he found time to chair the Commission for Pharmacology and Pharmacy of the Ministry of Health and an Expert Commission for protection of laboratory animals in Charles University. He spent 13 years working on two important framework research projects of Charles University and was a prominent member of the project "Psychopharmacological Research at Charles University". More recently, he regularly contributed largely philosophical essays for the magazine Vita Nostra Revue of Charles University.

Milos died on August 28, 2016 after a long illness. $\mathrm{He}$ is survived by his wife Milena, whom he married in 1963 and by a son, a daughter and four grandchildren. In addition to his outstanding scientific, educational and other professional activities, Milos Kršiak was always prepared to help everyone within the width of his professional and human skills and was always totally reliable and fair in his relations with colleagues. He is irreplaceable, but his legacy is outstanding and those who knew him will never forget him and surely will follow his example. 